\title{
The ECONOMIC VALUE OF FLOWER TOURISM AT THE NAMAQUa National Park, South Africa
}

\author{
Ivor James and Timm Hoffman \\ Botany Department, University of Cape Town \\ Alistair Munro \\ Economics Department, University of London \\ Patrick O'Farrell \\ CSIR, Natural resources and the Environment, Stellenbosch \\ Russel Smart \\ Namaqualand National Park, Kamieskroon
}

\begin{abstract}
The travel cost method was used to estimate the economic recreational value of flower viewing at the Namaqua National Park. Demographic, time, expenditure, preference and route information was collected by means of interviews with 160 South African nationals who visited the park in their own vehicles. Visitors spent an average of \$US108 on transportation and \$US84 on accommodation in the region. A zonal travel-cost model was developed which suggests that flower viewing is of greater economic recreational value than the annual net loss to the park of \$US50 000 when only its expenses and revenue are considered.
\end{abstract}

Abstract

JEL Q26, 50

\section{1}

\section{Introduction}

Flower tourism is a well-recognised activity and significant revenue generator in the semi-arid, winter rainfall regions of South Africa (Turpie \& Joubert, 2004). However, the diversity and ecological systems sustaining it are under pressure from a range of factors that include: mining; agriculture (livestock and cereal production); alien plant invasions; unsustainable resource harvesting (particularly in the communal areas); and the illegal trade in succulent plants (Cowling \& Pierce, 1999; Siegfried, 1999). Consequently, 936 of the biome's plant species are listed as threatened on the IUCN Red Data list (IUCN, 2004). Siegfried (1999) argues that effective policy on land use in Namaqualand will be achieved only once fundamental questions concerning the sustainability, value and efficiency of the region's land-use sectors have been answered. This is true particularly for those land-use sectors whose production processes, or part thereof, fall outside formal market systems. One such sector is conservation, which has been viewed as a financial sink, because simple revenue (entrance fees) less running cost calculations is usually used to estimate its economic value. National parks in this region often make net losses per annum, which is regularly cited as a reason for limiting park funding or diverting investment away from the park.

Over the last two decades there has been an increasing focus on valuing non-market (nonpriced) environmental goods and services, and levels of biodiversity (Naidoo \& Adamowics, 2005). There is now a vast array of techniques for estimating the value of these goods and services. These methods place monetary values on the benefit or welfare that individuals obtain from these goods and services. Welfare is estimated by 
analysing individuals' behaviour when changes in the price, quantity or characteristics of the goods or services occur (Boxall \& Beckley, 2002). This can be done by observing people's behaviour and preferences in real-world settings.

In this study, we use a revealed preference method, namely, the travel-cost method (TCM) to estimate the economic recreational value of flower viewing at the Namaqua National Park (NNP) in the Namaqualand region of South Africa. The results indicate that the economic value brought to the region by tourists is in an order of magnitude larger than the park's annual net losses, and extends well beyond the revenue it generates.

\subsection{Study area}

The Namaqua National Park (NNP) is a 70000 ha state-funded protected area located in central Namaqualand, a geographic region within the Succulent Karoo Biome (Figure 1). Namaqualand is a semi-arid region (150$400 \mathrm{~mm}$ per annum) and is roughly $50000 \mathrm{~km}^{2}$ in extent. It contains an exceptional diversity of plants, insects and reptiles (Cowling \& Pierce, 1999) and forms part of an internationallyrecognized biodiversity "hotspot" (Mittermeier et al., 2004). Namaqualand is most famous for the region's spectacular floral displays during late winter and spring. These floral displays draw large numbers of tourists and the NNP serves as one of the centres for the trade (Loubser $e t$ al., 2001). As many as 10000 tourists visit the NNP from August to September, but annual visiting varies in response to the quality of the flowers. For the remainder of the year there are, according to park managers, virtually no visitors. The NNP makes an average net loss of \$US50 000 per annum, although the park's full economic value to the region has not yet been determined.

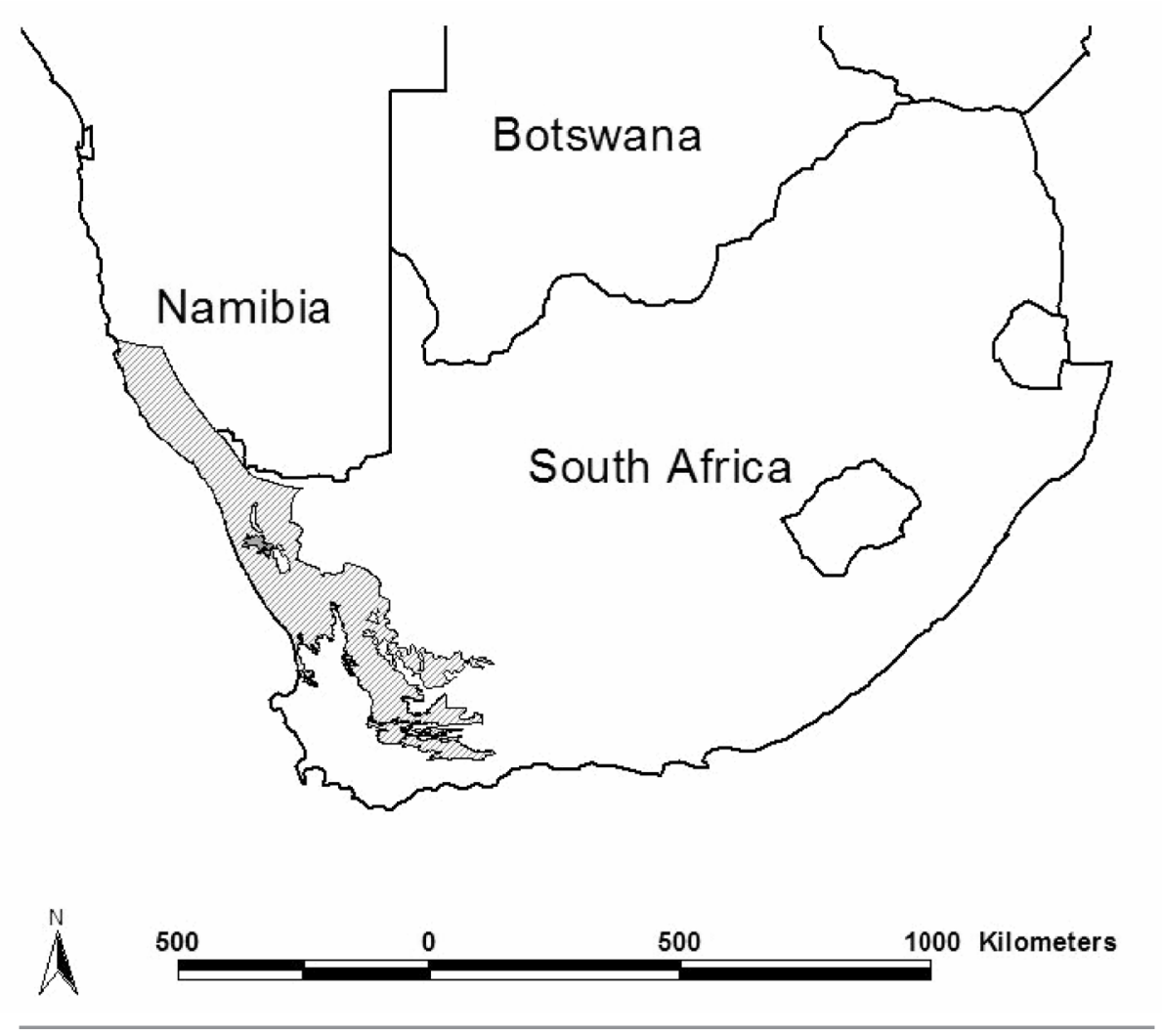

Figure 1

The location of the 70,000 ha Namaqua National Park (NNP) within the broader Namaqualand region of the Succulent Karoo biome in the western part of southern Africa. 


\subsection{Methods}

\section{Data collection}

A detailed questionnaire was developed for the purpose of interviewing visitors to the NNP during the 2002 flower season. Interviewers stationed themselves in the visitors' centre in the NNP during open times for the gate during the flower season and asked visiting tourists to the centre whether they were willing to participate in the study. A complete sample could not be obtained, as visitors arrived and left the centre before an interview could be requested. This occurred when an interviewer was already engaged in an interview. Interviews were conducted in both English and Afrikaans and only a single member of a party or group was interviewed. The information collected is listed below.

- Demographic information: age, sex, marital status, home language, home location, profession and income;

- Time information: trip length, travel time, length of time spent in Namaqualand and whether the respondent was on paid leave or a week-end break;

- Expenditure information: car engine capacity; number of people in the car; and daily transportation per person, accommodation, food and other expenditure estimates;

- Preference information: respondents were asked to state the number of visits made to the NNP per year; whether they had visited the NNP before; how their visit to the NNP fitted in with their trip; the main activity they wished to pursue, or reason for visiting Namaqualand and the NNP; and to describe as a percentage the contribution that the prospect of visiting the NNP made towards their decision to take the trip;

- Route information: respondents were given maps of South Africa and Namaqualand, onto which they traced their round trip route, indicating the places they had visited or planned to visit and the length of time spent on each visited site, and its ranking.

\section{Data analysis}

\section{Travel-cost method}

We used the zonal travel-cost method (ZTCM) in this study. Visitors to the NNP were grouped into zones of increasing distance from the site and the trip-generating function (TGF) was estimated by regressing the visiting rate from each zone against zonal average variables. It was assumed that individuals in each zone had identical demand parameters and did not therefore reflect utility-maximising behaviour (Brown \& Nawas, 1973). Separate zones were defined for each visitor's origin. Distances from respondents' residences to the town in Namaqualand where they had based themselves were estimated, using the routes indicated by respondents in the mapping exercise. Zonal averages were obtained and zones were amalgamated if their average one-way distances differed by fewer than $100 \mathrm{~km}$. Using this method, nine zones were described, one for every province in South Africa. The remainder of the sample were identified according to their provincial location and amalgamated into the respective zones. Visiting rates were based on the zones as well as on an estimation of travel distance which was used to calculate travel time and expenditure.

Zonal visiting rates were estimated using:

Visiting rate $=\frac{V i s_{p}}{P o p_{p}} \times 1000$

Visp is the number of visitors from zone $p$ (calculated from the NNP's gate record) and Popp is the provincial population of white people with household incomes above $\$ 6000$ per annum (the South African average). Data was obtained from the 2001 census and the visiting rate is expressed as the number of visitors per thousand. According to Maille and Mendelsohn (1993), the population used for estimating the visiting rate must reflect those individuals with the potential to visit the site. As the majority of visitors were relatively affluent white South Africans, the sub-sample used is appropriate. 


\section{The trip-generating function (TGF)}

Table 1 describes the variables used to calculate the TGF. Both a top-down and a bottom-up approach for including variables in regressions were attempted and only significant variables were retained. Namaqualand is considered an independent site, so no variable dealing with the effect of substitute sites was involved.

\section{Table 1}

A description of the model variables used in developing the trip generating function (TGF) for the zonal travel cost model.

\begin{tabular}{|l|l|}
\hline Variable & Description \\
\hline Visitation rate & Dependent variable, visits per 1000 people. \\
\hline In (Visitation rate) & Dependent variable, natural log of Visitation Rate. \\
\hline Gender & Dummy variables for male to female ratios of between $0.4-0.6,>0.4$ and $<0.4$. \\
\hline Income & Zonal average annual income. \\
\hline Age & Average zonal age. \\
\hline Age2 & Average zonal age squared. \\
\hline Home language & Dummy variable indicating the dominant language of visitors from each zone. \\
\hline Marital status & $\begin{array}{l}\text { Dummy variable taking a value of } 1 \text { if more than } 80 \% \text { of the zones sample were } \\
\text { married and } 0 \text { otherwise. }\end{array}$ \\
\hline Retired & $\begin{array}{l}\text { Dummy variable taking a value of } 1 \text { if more than } 60 \% \text { of the zones population was } \\
\text { retired and } 0 \text { otherwise. }\end{array}$ \\
\hline Trip length & Average trip length for each zone in days. \\
\hline Nights & Average number of nights spent. \\
\hline Travel cost & \begin{tabular}{l} 
The several different travel cost specifications are discussed below. \\
\hline
\end{tabular} \\
\hline
\end{tabular}

\section{The travel costs}

The estimation of travel costs includes both travel expenditure and time. Four definitions of trip expenditure and two methods of calculating the travel expenditure were used. First, respondents were asked to state the daily travel expenditure per person. This was multiplied by the trip length to obtain a total transportation cost per person. Second, an estimated cost was obtained by multiplying a constant per $\mathrm{km}$ running-cost estimate of the respondents' roundtrip distance. This estimate was then divided by the number of people in the car to obtain an estimate per person. The constant per $\mathrm{km}$ running-cost estimate included repairs, tyres and fuel costs and ranged between \$US0.0602 - \$US0.1052 depending on the engine capacity of the respondent's car. Added to this estimate were the respondent's transportation costs in Namaqualand. These were calculated by multiplying the same per $\mathrm{km}$ rate by the number of $\mathrm{km}$ travelled in Namaqualand (estimated from the mapping exercise in the survey) divided by the number of people in the car. These two travel expenditure measures were then averaged and used as the first two travel-expenditure specifications. The remaining two travel-expenditure specifications were obtained by adding on-site expenditure to the above specifications. The only on-site expenditure essential to taking a trip was accommodation. Thus, the average total per person accommodation expenditure was added to both price specifications above.

Four methods of dealing with time were attempted to examine the sensitivity of consumer surplus estimates to changes in assumptions and cost-accounting practices. First, the opportunity cost of time was valued at zero. Although it is unlikely that visitors to the NNP valued their 
time at zero, 80 per cent of the sample consisted of pensioners on either an annual vacation or a week-end break. It is therefore unlikely that there would be any forgone income associated with their visit and valuing time at zero may be valid.

Second, time was valued at 100 per cent of an individual's after-tax income. As pensioners, who do not work but receive an income, dominate the sample it can be argued that their opportunity cost of time is constant for every day of the year. Hence, the pensioners' after-tax income was divided by 365 and multiplied by the stated length of the trip. Of the remainder of the sample, 70 per cent were individuals on unpaid leave. These individuals are at interior solutions in the labour-leisure supply model and their opportunity cost of time can be valued at their wage rate (Bockstael et al., 1987). Their after-tax incomes were therefore divided by 241 (average number of work days in South Africa) and then multiplied by the trip length.

Third, time was treated as a constraint and the total trip time in days was therefore entered into the TGF as a separate variable. Because 80 per cent of the sample contained people who could not freely substitute income for leisure (pensioners and people on paid leave or weekend breaks) it can be argued that they were outside or at corner solutions in the leisurelabour supply model. Hence, the opportunity cost of time cannot be estimated at the wage rate, and time (days) should be entered as a separate argument in the TGF (Bockstael et al., 1987).

Fourth, some relationship between the wage rate and the opportunity cost of time was assumed to exist, and sensitivity analysis was used to find this fraction. Thus, time was valued at numerous fractions of the wage rate (where the second specification was followed to estimate the wage rate) and the fraction best fitting the data was presented.

Most studies estimate the total amount of time spent in recreation as the on-site time plus the travelling time. When on-site time is, constant over the sample, negligible relative to travelling time, and is not correlated to other explanatory variables in the model, its exclusion is considered harmless (Bockstael, 1995). Furthermore, most studies use some government travelling time estimate or employ advanced road engineering or GIS software packages to estimate travelling time (Brainard et al., 1997). In this study, on-site time in Namaqualand was not constant across the sample, and was correlated with distance. The first, second and fourth specifications above the trip length stated by respondents were multiplied by the per day opportunity cost of time. These were then added to the four travel expenditure specifications to obtain travel-cost estimates.

\section{The functional form of the TGF}

The use of the ZTCM negates the possibility that the sample is truncated and the broad categorisation of zones removes the possibility of censoring, as no zones have zero visitors. Hence, the following log-linear (equation 2):

$\log =\beta_{0}+\beta_{1} T C+\sum \beta_{\mathrm{j}} X_{\mathrm{j}}+e(\mathrm{~V})$

Where $\mathrm{V}$ is the visiting rate; $\beta_{0}$ is the constant term; $\beta_{1}$ and $\beta_{2}$ are the parameters on the travel cost variable (TC) and its square, respectively. $\sum \beta_{\mathrm{j}} X_{\mathrm{j}}$ represents all the socio-economic shift variables included; and $e$ is the random error term. All variables were tested and insignificant variables were dropped. Final models were selected on the basis of coefficients having the expected signs, the significance of the variables, the $\mathrm{R}^{2}$, and the absence of heteroskedasticity and multicollinearity (where the presence of heteroskedasticity was tested for using both the White and the Breusch-Pagan test). The latter method is applicable when there is prior knowledge of the variable causing the heteroskedasticity (population size).

\section{Multiple purpose and destination visitors}

The travel costs do not require correction for multiple-purpose visitors, as 98.6 per cent of all visitors came to Namaqualand to view flowers. Nor are meanderers a problem, because this study follows the general trend of assuming that travel time yields no utility (see among others Liston-Heyes \& Heyes, 1999). However, the travel-cost variable should be corrected for multiple destination trip (MDT) visitors, as 100 per cent of the sample visited more than one 
site. This was initially done using the extreme value approach (EVA) (Kmietowicz \& Pearman, 1981). However, once the travel costs were corrected the minimum value models yielded poor $\mathrm{R}^{2}$ values and none of the variables were significant. The EVA approach was therefore adapted by taking each zone's average minimum and maximum cost-share values and multiplying them by the consumer surplus (CS) estimated when full travel costs were used. This approach follows that of Navrud and Mungatana (1994), but the visitors' preferences are used instead of time to portion the total CS. Another measure of preference, the average zonal stated percentage that the prospect of visiting the NNP contributed to the decision to take the trip, was also used to estimate the NNP's CS share.

\section{Estimating the consumer surplus (CS)}

CS for the log-linear model was obtained using the formula:

$$
\mathrm{CS}=\frac{1}{-\beta_{T C}}
$$

Where, $\beta_{\mathrm{TC}}$ is the coefficient on the travel cost variable (Creel \& Loomis, 1990; English \& Bowker, 1996). This estimate was then multiplied by the average zonal minimum, stated and maximum CS shares, and by the number of visitors from each zone. Summing across the zones yielded the total CS.

\section{2 \\ Results}

\subsection{Visitor numbers and origins}

During the 2002 flower season, the NNP received 9707 visitors. Of these, 1258 were foreigners and 8449 were South African nationals. Of the latter group, 7257 travelled in 2419 cars and 1192 travelled in 85 buses. A total of 204 visitors were interviewed, of whom 31 were foreigners in buses, 33 were locals in buses and 160 were locals in their own cars. Owing to the low sample sizes, only the local own-car visitors were analysed. With an average of 3.5 people to a car, our sample represents 6.6 per cent of visitors in cars to the park.

More than 90 per cent of the visitors originated from the highly-developed urban areas in South Africa. Visitors from the Gauteng Province and the City of Cape Town in the Western Cape Province account for 43 per cent and 25 per cent of the visitors respectively. The remaining visitors came from the urban areas of the east coast and the far north eastern regions as well as the central and central-north regions of South Africa.

\subsection{Demographic characteristics}

The average age of the visitors was 56 years (Table 2). However, 73 per cent of the sample was older than 55 years and 65 per cent were pensioners. The majority ( $\mathrm{n}>95$ per cent) of the sample belonged to the same racial group (white) and spoke Afrikaans (60 per cent) or English (40 per cent) as home languages. Furthermore, 85 per cent were married and the male to female ratio of visitors was 1.04. The lowest reported income was higher than the South African average and the average income was more than double the South African average.

\section{Table 2}

The age and income of 160 local visitors who visited the Namaqua National Park in their own car in the spring of 2002. Income data are presented in $\$$ US where $\$ \cup S 1=$ R10

\begin{tabular}{|l|c|c|c|c|}
\hline Variable & Mean & Median & Maximum & Minimum \\
\hline Age & 56 & 61 & $>65$ & $<18$ \\
\hline Income $(\$ \cup S)$ & 17831 & 20500 & $<35000$ & 7500 \\
\hline
\end{tabular}




\subsection{Preferences and reasons for making the trip}

Almost all of the visitors (98.6 per cent) stated that flower viewing was their main reason for coming to Namaqualand. Furthermore, 64 per cent of the sample stated that their visit to the Namaqua National Park (NNP) played a significant or central role in their decision to make the trip and the average contribution (as a percentage) that the prospect of visiting the NNP made to visitors' decisions to take the trip was 36 per cent (Table 3 ). More than 70 per cent of the respondents were visiting the park for the first time and less than 1 per cent visited the park more than once a year. As far as site preferences were concerned, the average number of sites visited was 3.6 and 95 per cent of respondents gave the NNP the highest ranking.

\section{Table 3}

The contribution of the Namaqua National Park (NNP) towards the decision to make the trip to Namaqualand for 160 local visitors in their own car and the number of sites visited in the region.

\begin{tabular}{|l|c|c|c|c|}
\hline Variable & Mean & Median & Maximum & Minimum \\
\hline \% contribution of the NNP towards the trip decision & 36 & 30 & 85 & 0 \\
\hline Number of sites visited in Namaqualand & 3.6 & 4 & 6 & 2 \\
\hline
\end{tabular}

\subsection{Length of trip and expenditures}

The average round trip distance of $1844 \mathrm{~km}$ made by visitors to the Namaqua National Park (NNP) in 2002 (Table 4) reflects the relative remoteness of Namaqualand. It is no surprise that there were no day-trippers to Namaqualand and the average duration of trips to the region was 7.4 days. However, all visitors to the NNP itself are, in a sense, day-visitors, as no accommodation is offered at the park. The average on-site time for 95 per cent of the respondents to the NNP was less than 5 hours. Thus, although nearly all the visitors to Namaqualand come to view flowers, and the prospect of visiting the NNP contributes significantly towards their trip decision (see above), they spend a relatively small proportion of their trip time at the park. Instead, more than 95 per cent of the visitors undertake day trips from their base in one of the NNP's surrounding towns and spend an average of 4.7 nights in the region. The range in the total stated transport and accommodation expenditures for the trip to Namaqualand suggests that some people make shorter, cheaper trips, while others make longer, more expensive trips.

Table 4

Summary statistics for the length of the journey made by 160 local visitors to the Namaqua National Park (NNP)) in the spring of 2002 as well as their expenditure on transport and accommodation (in \$US where $\$ \cup S 1=\mathrm{R} 10$ ).

\begin{tabular}{|c|c|c|c|c|}
\hline Variable & Mean & Median & Maximum & Minimum \\
\hline Trip length (days) & 7.4 & 7 & 14 & 2 \\
\hline Number of days spent in Namaqualand & 4.7 & 4 & 13 & 1 \\
\hline Round trip distance $(\mathrm{km})$ & 1844 & 2352 & 3320 & 360 \\
\hline Average $\mathrm{km}$ travelled in Namaqualand per day & 179 & 202 & 250 & 100 \\
\hline Total transportation costs (\$US) & 108 & 132 & 315 & 29 \\
\hline Total accommodation costs (\$US) & 84 & 92 & 150 & 15 \\
\hline
\end{tabular}




\subsection{The relationships between trip description variables}

Table 5 is a correlation matrix describing the strength $(x)$ of the linear association between different trip description variables (where, $-1 \leq x \leq 1$ ). The round trip distance variable is positively correlated with daily transport costs, daily accommodation costs and the length of time spent in Namaqualand. Thus, as distance increases, it costs more to get to the site, individuals spend more on accommodation (per day) and the length of time spent in Namaqualand increases. For the remaining variables it is important to note that: individuals whose travel expenditure is greater spend more on accommodation and remain longer in Namaqualand. Daily accommodation expenditures are higher for older people, but decline when the length of the trip increases. Older people make shorter trips than younger people, and place more emphasis on the NNP in their trip decision process.

\section{Table 5}

Correlation matrix for a number of trip description variables derived from a survey of 160 local visitors to the Namaqua National Park in the spring of 2002.

\begin{tabular}{|l|c|c|c|c|c|c|}
\hline & A & B & C & D & E & F \\
\hline A. Round trip distance to Namaqualand & 1 & & & & & \\
\hline B. Daily travel costs & 0.45 & 1 & & & & \\
\hline C. Daily accommodation costs & 0.12 & 0.41 & 1 & & & \\
\hline D. Days in Namaqualand & 0.47 & 0.24 & -0.14 & 1 & & \\
\hline E. Age & -0.07 & 0.22 & 0.12 & -0.35 & 1 & \\
\hline F. Percentage of reason for taking the trip & -0.59 & -0.14 & 0.05 & -0.46 & 0.38 & 1 \\
\hline
\end{tabular}

\subsection{The zones, round trip distances and visitor information}

The zones presented in Table 6 are in order of ascending distance from the site. If the TCM assumption holds, then visiting rates should, by default, be in ascending order. This is largely the case, but the visiting rates for the Limpopo, the Free State and the North West provinces are slightly higher than expected. This may be owing to the small populations in these regions.

\section{Table 6}

The zones from which visitors to the Namaqua National Park (NNP) originate, the average round trip distance and the visitation rates. Data are derived from a survey of 160 local visitors to the NNP in the spring of 2002.

\begin{tabular}{|l|c|c|c|}
\hline Zone & $\begin{array}{c}\text { Average round trip } \\
\text { distance }(\mathbf{k m})\end{array}$ & Fraction of total visitors & $\begin{array}{c}\text { Visitation rate (visits } \\
\text { per 1000 people) }\end{array}$ \\
\hline Northern Cape & 600 & 0.07 & 21.0 \\
\hline Western Cape & 1160 & 0.25 & 7.5 \\
\hline North West & 1765 & 0.06 & 7.8 \\
\hline Free State & 2220 & 0.06 & 8.1 \\
\hline Gauteng & 2380 & 0.43 & 5.0 \\
\hline Eastern Cape & 2555 & 0.03 & 2.3 \\
\hline
\end{tabular}




\begin{tabular}{|l|c|c|c|}
\hline Limpopo & 2970 & 0.02 & 5.3 \\
\hline Mpumalanga & 3120 & 0.02 & 3.2 \\
\hline KwaZulu-Natal & 3320 & 0.06 & 3.0 \\
\hline
\end{tabular}

\subsection{The log-linear models}

None of the log-linear models suffered from heteroskedasticity. Both the White and the Bruesch-Pagan tests yielded test statistics leading to the non-rejection of the null hypothesis of homoskedasticity at the 95 per cent confidence level. In all models the only significant variable other than travel cost was income.

Table 7 describes the log-linear models obtained when the opportunity cost of time was valued at zero. For all travel-cost definitions the signs on the travel cost and income variables are negative and positive, respectively. Thus, higher travel costs and lower incomes reduce the visiting rate for all models. Furthermore, all the variables are significant at the 95 per cent level except income in the two stated cost models, which is significant at the 90 per cent level. The best model is the estimated travel expenditure plus accommodation model, as it has the highest $\mathrm{R}^{2}$ and highly significant variables.

Furthermore, stated travel costs are between 5-10 per cent higher than the estimated travel costs. Hence, the coefficients on the stated travel cost variables are lower than those on their estimated travel-cost counterparts. This is reflected in the consumer surplus (CS) per person estimates, where the stated travel-cost CS estimates are higher than those obtained when the estimated travel costs are used. When accommodation is included in the travel-cost definition, the CS estimates almost double, regardless of whether stated or estimated travel costs are used. Maximum CS estimates are more than three times the minimum estimates, and the stated CS estimates are higher than the minimum estimates, but are at least 50 per cent lower than the maximum estimates.

Table 7

Results of the regressions ( + standard error) when the opportunity cost of time is valued at zero (dependent variable $=\log$ visitation per 1000 people, $\mathrm{N}=9$ ). ${ }^{*}=\mathrm{p}<0.10 ;{ }^{* *}=\mathrm{p}<0.05$.

\begin{tabular}{|c|c|c|c|c|}
\hline Variable & Stated travel cost & $\begin{array}{l}\text { Stated travel } \\
\text { cost plus } \\
\text { accommodation }\end{array}$ & $\begin{array}{c}\text { Estimated travel } \\
\text { cost }\end{array}$ & $\begin{array}{l}\text { Estimated } \\
\text { travel cost plus } \\
\text { accommodation }\end{array}$ \\
\hline Travel cost & $\begin{array}{r}-0.001483^{* *} \\
(0.0002457)\end{array}$ & $\begin{array}{l}-0.0008258^{* *} \\
(0.0001141)\end{array}$ & $\begin{array}{c}-0.0017088^{* *} \\
(0.0003386)\end{array}$ & $\begin{array}{l}-0.0009356^{* *} \\
(0.0001143)\end{array}$ \\
\hline Income & $\begin{array}{l}3.11 \mathrm{e}-06^{*} \\
(1.97 \times 10-6)\end{array}$ & $\begin{array}{l}2.79 \mathrm{e}-06^{*} \\
(1.68 \times 10-6)\end{array}$ & $\begin{array}{l}7.15 \mathrm{e}-06^{* *} \\
(2.35 \times 10-6)\end{array}$ & $\begin{array}{l}4.91 \mathrm{e}-06^{* *} \\
(1.50 \times 10-6)\end{array}$ \\
\hline Constant & $\begin{array}{c}2.457547^{* *} \\
(0.5031487)\end{array}$ & $\begin{array}{c}2.671976^{* *} \\
(0.4427193)\end{array}$ & $\begin{array}{c}1.751084^{* *} \\
(0.5268508)\end{array}$ & $\begin{array}{c}2.393542 \\
(0.3760704)\end{array}$ \\
\hline $\mathrm{R}^{2}$ & 0.8722 & 0.9071 & 0.8276 & 0.9258 \\
\hline Adjusted $\mathrm{R}^{2}$ & 0.8296 & 0.8761 & 0.7702 & 0.901 \\
\hline CS per person (\$US) & 67.431 & 122 & 58.5 & 107 \\
\hline Max total CS (\$US) & 489346.8 & 878784 & 424684 & 77562 \\
\hline Stated total CS (\$US) & 178228.03 & 320068 & 154677 & 282506 \\
\hline Min total CS (\$US) & 122336.48 & 219696 & 106171 & 193913 \\
\hline
\end{tabular}


Tables 8 and 9 describe the regression results when time is valued at 100 per cent and 43 per cent of the wage rate respectively. The later fraction is the British Department of Transport's opportunity cost of time estimate, which has been used extensively in studies in the UK (see Willis \& Garrod, 1990). Although many models with different fractions of the wage were generated, the results obtained follow a general pattern that is revealed when only one estimate is presented.

For both models the results follow the same pattern as those in the previous model. That is, all coefficients are significant at the 95 per cent level and have the expected signs (negative for travel cost and positive for income). They are larger for both the estimated specifications and smaller when accommodation is included. The $\mathrm{R}^{2}$ and adjusted $\mathrm{R}^{2}$ are very high, but highest for the estimated travel cost plus accommodation definition. Again, the CS estimates per person are least for the estimated specifications, larger when accommodation costs are included and the stated consumer surplus value is closer to the minimum CS value than to the maximum CS value, which is more than double the stated value.

\section{Table 8}

Results of the regressions ( + standard error) when the opportunity cost of time is valued at $100 \%$ of the wage rate (dependent variable $=\log$ visitation per 1000 people, $\mathrm{N}=9$ ). ${ }^{* *}=\mathrm{p}<0.05$.

\begin{tabular}{|l|c|c|c|c|}
\hline Variable & $\begin{array}{c}\text { Stated travel cost } \\
\text { plus opportunity } \\
\text { cost of time }\end{array}$ & $\begin{array}{c}\text { Stated travel } \\
\text { cost plus } \\
\text { accommodation } \\
\text { plus opportunity } \\
\text { cost of time }\end{array}$ & $\begin{array}{c}\text { Estimated } \\
\text { travel cost plus } \\
\text { opportunity cost } \\
\text { of time }\end{array}$ & $\begin{array}{c}\text { Estimated } \\
\text { travel cost plus } \\
\text { accommodation } \\
\text { plus opportunity } \\
\text { cost of time }\end{array}$ \\
\hline Travel cost & $-0.0006079^{* *}$ & $-0.0004553^{* *}$ & $-0.000646^{* *}$ & $-0.0004818^{* *}$ \\
$(0.0000536)$ & $(0.0000441)$ & $(0.0000623)$ & $(0.0000447)$ \\
\hline Income & $8.95 \times 10-6^{* *}$ & $7.32 \times 10-6^{* *}$ & $(0.0000108)^{* *}$ & $8.68 \times 10-6^{* *}$ \\
\hline Constant & $(1.18 \times 10-6)$ & $(1.24 \times 10-6)$ & $(1.36 \times 10-6)$ & $(1.23 \times 10-6)$ \\
\hline $\mathrm{R}^{2}$ & $1.546032^{* *}$ & $1.88234^{* *}$ & $1.230049^{* *}$ & $1.674145^{* *}$ \\
\hline Adjusted $\mathrm{R}^{2}$ & $(0.247378)$ & $(0.2805478)$ & $(0.2632537)$ & $(0.2628914)$ \\
\hline CS per person (\$US) & 0.93 & 0.9518 & 0.9523 & 0.9556 \\
\hline Max total CS (\$US) & 1193782 & 1593894 & 1123375 & 0.9408 \\
\hline Stated total CS (\$US) & 434796 & 580523 & 409152 & 207.5 \\
\hline Min total CS (\$US) & 298846 & 398473 & 280843 & 548593 \\
\hline
\end{tabular}




\section{Table 9}

Results of the regressions (+standard error) when the opportunity cost of time is given a valued at $43 \%$ of the wage rate (dependent variable $=\log$ visitation per 1000 people, $N=9$ ). ${ }^{* *}=p<0.05$.

\begin{tabular}{|l|c|c|c|c|}
\hline Variable & Stated travel cost & $\begin{array}{c}\text { Stated travel } \\
\text { cost plus } \\
\text { accommodation }\end{array}$ & $\begin{array}{c}\text { Estimated travel } \\
\text { cost }\end{array}$ & $\begin{array}{c}\text { Estimated } \\
\text { travel cost } \\
\text { accommodation }\end{array}$ \\
\hline Travel cost & $\begin{array}{c}-0.0009317^{* *} \\
(0.0000985)\end{array}$ & $\begin{array}{c}-0.0006155 \\
(0.0000682)\end{array}$ & $\begin{array}{c}-0.0010241^{* *} \\
(0.0001215)\end{array}$ & $\begin{array}{c}-0.000669^{* *} \\
((0.0000679)\end{array}$ \\
\hline Income & $6.94 \times 10-6^{* *}$ & $5.42 \times 10-6^{* *}$ & $9.73 \times 10-6^{* *}$ & $7.17 \times 10-6^{* *}$ \\
$(1.34 \times 10-6)$ & $(1.37 \times 10-6)$ & $(1.60 \times 10-6)$ & $(1.30 \times 10-6)$ \\
\hline Constant & $1.884422^{* *}$ & $2.224095^{* *}$ & $1.416925^{* *}$ & $1.971147^{* *}$ \\
\hline $\mathrm{R}^{2}$ & $(0.3049481)$ & $(0.3340613)$ & $(0.3238198)$ & $(0.2965327)$ \\
\hline Adjusted ${ }^{2}$ & 0.943 & 0.938 & 0.9296 & 0.9474 \\
\hline CS per person (\$US) & 0.924 & 0.917 & 0.9061 & 0.929 \\
\hline Max total CS (\$US) & 778899 & 1179041 & 97.6 & 162 \\
\hline Stated total CS (\$US) & 283688 & 429427 & 258092 & 429427 \\
\hline Min total CS (\$US) & 194725 & 294760 & 177156 & 294760 \\
\hline
\end{tabular}

Table 10 describes the model that includes time as an explanatory variable and the estimated travel cost (the price definition that yielded the strongest models) was used as the price definition.

\section{Table 10}

Results of the regression when time was included as a separate argument in the trip generating function (TGF) (dependent variable $=\log$ visitation per 1000 people, $\mathrm{N}=9$ )

\begin{tabular}{|l|c|c|c|c|}
\hline Variable & Coefficient & Standard error & t value & Probability \\
\hline Travel cost & -0.0006176 & 0.0005611 & -1.1 & 0.32 \\
\hline Income & $3.55 \times 10-6$ & $2.69 \times 10-6$ & -0.38 & 0.72 \\
\hline Time & -0.068 & 0.179 & 1.32 & 0.245 \\
\hline Constant & 2.036762 & 0.4953 & 5.29 & 0.003 \\
\hline
\end{tabular}

The results obtained above were replicated for every price specification and functional form in which time was included as a separate argument in the trip-generating function (TGF). That is, the $\mathrm{R}^{2}$ and adjusted $\mathrm{R}^{2}$ are very high $(0.92$ and 0.89 , respectively), but none of the variables are significant. According to Gujarati (1997), this is symptomatic of models suffering from multicollinearity. Hence, the opportunity cost of time was not endogenously modelled in this study.
The above results highlight the sensitivity of the consumer surplus (CS) estimates toward the travel expenditure and opportunity cost assumptions used. Maximum per person CS estimates ranged from \$US58.5 - \$US207, depending on whether stated or estimated travel costs are used, accommodation costs are included and the manner in which time is dealt with. Using stated travel cost estimates increases the CS by $5-10$ per cent. Including accommodation increases the consumer 
surplus by approximately 80 per cent, and the opportunity cost of time assumption causes the consumer surplus to increase by between 0 per cent -100 per cent with increasing fractions of the wage resulting in higher estimates.

The results also describe the bias resulting when there is no correction for multiple destination trip (MDT) visitors. The maximum values ranged between \$US424 684 and \$US1 193782 per annum, and were more than four times the minimum values (which ranged between \$US 106171 and \$US 298846 per annum) and more than double the stated values, which ranged between \$US154 677 and \$US434 796 per annum. Although there is a significant difference between the minimum and maximum values, the lowest minimum value is still larger than the NNP's average annual net loss of \$US50 000.

\section{3}

\section{Discussion}

Bearing in mind Willis and Garrod's (1990) caveat that the chosen model must contain significant variables, must have coefficients of the expected sign and a reasonable $\mathrm{R}^{2}$, and must produce CS estimates that are not an order of magnitude different from estimates obtained by other studies for similar sites, the log-linear models have been used to estimate the recreational value of flower viewing at the NNP. Furthermore, the most appropriate price and time specifications are discussed and a most-preferred value is presented. While we acknowledge the limited sample size of this study, we take much consolation in the matching demography and trends of the sampled population presented by Loubser et al. (2001), who conducted a similar study in the NNP with a sample size of 856 individuals, finding that most visitors to the region were also pensioners.

The log-linear models produced significant variables, coefficients of the expected sign, and high $\mathrm{R}^{2}$ values. Although high, the $\mathrm{R}^{2}$ values are in line with those of other ZTCM studies. Willis and Garrod (1990) evaluated a series of studies on forest recreation sites in the UK and found that ZTCM studies had $\mathrm{R}^{2}$ values ranging between 0.8 and 0.96 . In order to compare the log-linear model's results with those of other studies, per person per trip CS estimates were required (Table 11).

\section{Table 11}

The weighted average per person per trip consumer surplus (CS) estimates for the log-linear models, where weights correspond to the zonal CS share values.

\begin{tabular}{|l|c|c|c|c|}
\hline \multirow{2}{*}{$\begin{array}{l}\text { Time } \\
\text { Preference Share }\end{array}$} & \multicolumn{3}{|c|}{ Price Definition (In US\$ where \$US1= R10) } \\
\cline { 2 - 5 } & Stated travel cost & $\begin{array}{c}\text { Stated travel } \\
\text { cost plus } \\
\text { accommodation }\end{array}$ & $\begin{array}{c}\text { Estimated travel } \\
\text { cost }\end{array}$ & $\begin{array}{c}\text { Estimated } \\
\text { travel cost plus } \\
\text { accommodation }\end{array}$ \\
\hline Time valued at Zero & & & & \\
Minimum & 21.22 & 38.5 & 18.4 & 33.7 \\
Stated & 33.3 & 60.1 & 28.9 & 107 \\
Maximum & 67.4 & 122 & 58.5 & 51 \\
\hline Time valued at 43\% & & & & 80 \\
Minimum & 33.7 & 51.2 & 30.7 & 162 \\
Stated & 52.8 & 80.2 & 48.2 & \\
Maximum & 107 & 162.5 & 97.6 & 65.3 \\
\hline Time valued at 100\% & & & & 102.3 \\
Minimum & 51.8 & 69.13 & 48.7 & 207.5 \\
Stated & 80 & 108.4 & 76.4 & 154.8 \\
Maximum & 164.5 & 219.6 & & \\
\hline
\end{tabular}


The per person per trip CS (hereafter referred to as the per person CS) estimates range between \$US18.4 and \$US219.6. However, this includes the maximum CS share value, which is 100 per cent of the total CS value as the Namaqua National Park (NNP) was given the highest ranking by more than 95 per cent of the visitors. As Kuosmanen et al. (2003) argue, if multiple-destination trip (MDT) visitors are not corrected, the CS can be over estimated by as much as 50 per cent. In this study, ignoring the effects of MDT visitors overstates the CS by more than 50 per cent because the whole sample consists, in reality, of MDT visitors. The maximum values should therefore be excluded. If this is done, the per person CS estimates range from \$US18.4 to \$US108.4.

Furthermore, when the site is the mostpreferred site, the minimum value equals one divided by the number of sites. This implies that, if the remaining CS is divided equally among the remaining sites, then all sites will yield equal utility. However, if the remaining CS is not divided equally amongst the remaining sites, then at least once site yields more utility than the NNP. Because the NNP was given the highest ranking, no other site can yield an amount of utility greater than or equal to the utility yielded by the NNP. Hence, the minimum CS value underestimates the benefit derived from the NNP. The true CS therefore lies between the minimum and maximum values, but it is more likely to be closer to the minimum than the maximum value, as many utility-yielding sites were visited. The stated share values fulfil both these criteria. Thus, the preferred per person CS estimates now range from \$US28.9 to \$US108.4.

This range of CS estimates is dependent on the price definition and the cost of time measure employed with higher travel expenditure and travel cost specifications resulting in higher per person CS estimates. This finding is supported by a large number of studies (see Liston-Heyes \& Heyes, 1999, amongst others). English and Bowker (1996) argue that changing the functional form could lead to an 80 per cent difference in the CS, but changing the price specification could cause CS estimates to change by over 1000 per cent. Most studies therefore estimate a range of values supported by different assumptions.

There are a number of other studies for which per person CS estimates are available. For example, Liston-Heyes and Heyes (1999) valued a national park in England at between \$US35 -\$US97. Maille and Mendelsohn (1993) found that the value of ecotourism in Madagascar ranged from \$US276 to \$US360. Shrethsa et al. (2002) found that the value of recreational fishing in a region of Brazil was between \$US540-\$US869. Creel and Loomis (1990) estimated the value of hunting in California at between \$US74-\$US163, while Navrud and Mungatana (1994) estimated the value of wildlife viewing at a Kenyan National Park for local visitors at between \$US68 - \$US85.

The range of stated share CS values most preferred by this study is lower than the CS values for the Madagascan and Brazilian studies, but the Madagascan study included air fares while the Brazilian study contained an average round-trip distance of $2870 \mathrm{~km}$. These results are therefore bound to be higher. The values estimated by the remaining studies are remarkably similar to the stated share CS values. Thus, the log-linear models that use the stated share to partition the CS fulfil all Willis and Garrod's (1990) criteria.

The stated travel expenditures are only 5-10 per cent larger than the estimated values. Both Willis and Garrod (1990) and English and Bowker (1996) observed similar discrepancies between stated and estimated values, when estimated values were approximated using full car costs. Thus, the stated values in this study should be a fair approximation of the costs faced by visitors. However, in keeping with the general trend in the literature, this study considers the estimated costs to be a better proxy for trip price. Accommodation expenditure should be included, as visitors view this as part of the trip price. As far as time is concerned, both the zero and 100 per cent value of time definitions are plausible. However, the 43 per cent specification has no theoretical backing, because if we assume that people can freely substitute income for leisure (an implicit assumption of this formulation) then we should value their time at 100 per cent of the wage and not some fraction thereof (Bockstael et al., 1987). 
Hence, the most theoretically correct estimates are the stated CS shares for the estimated travel expenditure that includes accommodation and values time at either zero or 100 percent of the wage rate. The site's CS values are therefore between \$US282 506 and \$US548 593. These economic values are comparable to the US $\$ 235$ 000 suggested by Turpie and Joubert (2004) for a substantially smaller region (the Bokkeveld Plateau) south east of Namaqualand and are 5 to 11 times larger than the Namaqua National Park's annual net loss of \$US50 000. Furthermore, for every CS share functional form and price specification presented, the estimated site CS was larger than the park's net loss. Indeed, even the lowest CS estimate of \$US122 337 is more than double this amount. In addition, the economic values presented here exclude foreign tourists and locals who visited in buses. These economic values are therefore an underestimation of the economic recreational value of flower viewing at the NNP.

\section{4 \\ Conclusion}

This paper shows that the economic recreational value of flower viewing at the NNP is far larger than the annual net loss made by the park. The economic values presented here underestimate the NNP's value, because the social services it renders and its contribution to the local economy have been ignored. Nonetheless, even a fraction of the park's value (the economic recreational value) is greater than the costs of running the park.

\section{References}

1 BOCKSTAEL, N.E. (1995) "Travel cost models", in D.W. Bromley (ed.) The Handbook of Environmental Economics, Blackwell Ltd: Oxford, pp. 655-671.

2 BOCHSTAEL, N.E.; STRAND, I.E. \& HANEMANN, W.M. (1987) "Time and the recreational demand model", American Journal of Agricultural Economics, 69(2): 293-302.

3 BOXALL, P.C \& BECKLEY, T. (2002) "An introduction to approaches and issues for measuring non-market values in developing economies”, in B. Campbell \& M Luckert (eds.) Uncovering the Hidden Harvest, Earthscan: London, 103-140.

4 BRAINARD, J.; LOVETT, A. \& BATEMAN, I. (1997) "Using isochrone surfaces in travel cost models”, Journal of Transport Geography, 5(2): 117-126.

5 BROWN, W.G. \& NAWAS, F. (1973) "Impact of aggregation on the estimation of out door recreation demand functions", American Journal of Agricultural Economics, 55: 246-249.

6 COWLING, R.M. \& PIERCE, S.M. (1999) Namaqualand: A Succulent Desert, Struik Publishers: Cape Town.

7 CREEL, M.D. \& LOOMIS, J.B. (1990) "Theoretical and empirical advantages of truncated count data estimators for analysis of deer hunting in California", American Journal of Agricultural Economics, May: 434-441.

8 ENGLISH, B.K. \& BOWKER, J.M. (1996) “The sensitivity of white-water rafting consumer surplus to pecuniary travel cost specifications", Journal of Environmental Management, 47: 79-91

9 GUJARATI, D.N. (1995) Basic Econometrics (3 ${ }^{\text {rd }}$ ed.) McGraw Hill: New York.

10 IUCN (2004) Red Data list, available at: www.iucn. org.

11 KUOSMANEN, T.; NILLESEN, E. \& WESSELER, J. (2004) "Does ignoring multidestination trips in the travel cost method cause a systematic downward bias?", Australian Journal of Agricultural and Resource Economics, 48: 629-651.

12 KMIETOWICZ, Z.W. \& PEARMAN, A.D. (1981) Decision Theory and Incomplete Knowledge, Aldershot: Gower.

13 LISTON-HEYES, C. \& HEYES, A. (1999)

"Recreational benefits from the Dartmoor National Park", Journal of Environmental Management, 55: 69-80.

14 LOUBSER, G.J.J., MOUTON, P. \& NEL, J.A.J. (2001) "The ecotourism of herpetofauna in the Namaqua National Park, South Africa", South African Journal of Wildlife Research, 31(1): 13-23.

15 MAILLE, P. \& MENDELSOHN, R. (1993) "Valuing ecotourism in Madagascar", Journal of Environmental Management, 38: 213-218.

16 MITTERMEIER, R.A.; GIL, P.R.; HOFFMAN, M.; PILGRIM, J.; BROOKS, T.; MITTERMEIER, C.G.; LAMOREUX, J. \& DA FONSECA, G.A.B. (2004) Hotspots Revisited, Cemex: Mexico City.

17 NAIDOO, R. \& ADAMOWICS, W.L. (2005)

"Biodiversity and nature-based tourism at 
forest reserves in Uganda", Environment and Development Economics, 10: 159-178.

18 NAVRUD, S. \& MUNGATANA, E.D. (1994) "Environmental valuation in developing countries: The recreational value of wildlife viewing", Ecological Economics, 11: 135-151.

19 SHRESTHA, R.K.; SEIDL, A.F. \& MORAES, A.S. (2002) "Value of recreational fishing in the Brazilian Pantanal: a travel cost analysis using count data models", Ecological Economics, 42: 289-299.
20 SIEGFRIED, W.R. (1999) "Human impacts", in: S.J. Milton \& W.R J Dean (eds.), The Karoo, Cambridge University Press: Cambridge, 239-240.

21 TURPIE, J. \& JOUBERT, A. (2004) "The value of flower tourism on the Bokkeveld Plateau - a botanical hotspot", Development Southern Africa, 21: 645-662.

22 WILLIS, K.G. \& GARROD, G. (1990) "Valuing open access recreation on inland waterways", Working Paper 12, Countryside Change Unit: Newcastle University. 